ELORE (ISSN 1456-3010), vol. $18-1 / 2011$.

Julkaisija: Suomen Kansantietouden Tutkijain Seura ry.

[http://www.elore.fi/arkisto/1_11/art_lauhakangas.pdf]



\title{
INTERNETIN KESKUSTELUFOORUMIT SANANLASKUJEN KASVUALUSTANA
}

\section{$\underline{\text { Outi Lauhakangas }}$}

Internetin tekstit tarjoavat uuden lupaavan kentän sananlaskujen ja niiden muunnosten tutkimiseen todellisissa käyttöyhteyksissään. Aiemmin kirjallisuuslähteisiin perustuva tai arkitilanteissa työläs ja sattumanvarainen sananlaskujen käyttötilanteiden tutkiminen on nyt systemaattisempaa. Kirjallisen viestinnän tallentuessa yksityiskohtaisesti tutkittavaksi voi spontaanejakin tilanteita ikään kuin kelata taaksepäin ja tehdä oletuksia repliikkiin johtaneista tekijöistä.

Nettikirjoittaminen ei ole yhtenäinen kielimuoto. Sananlaskujen käytön tutkimuksen kannalta kiinnostavimpia ovat tekstilajit, jotka nettiviestinnässä ovat kehittyneet puheenomaista kirjoittamista suosiviksi. Voidaankin kysyä, mitä käytäntöjä puhevuorovaikutuksesta siirtyy nettikirjoittamiseen ja vastaavasti, mitä kirjoittaminen tuo keskustelunomaiseen ajatusten ilmaisemiseen. Onko sananlaskuilla samat tehtävät nettivuorovaikutuksessa kuin kasvokkaisissa kohtaamistilanteissa? Teen tekstianalyysin kommenttiaineistosta, joka löytyy eräältä nettifoorumilta. Analyysi tehdään niiden funktioiden pohjalta, joita on aiemmin eritelty tutkittaessa sananlaskujen käyttöä puhetilanteissa. Toinen tutkimusongelma, johon toivon valitsemani aineiston antavan lisävalaistusta on: Minkälaista identiteettiä anonyymi kirjoittaja rakentaa sellaisilla kielellisillä valinnoilla kuin sananlasku tai sananlaskumuunnos?

Nettitekstien valinnassa tutkimuksen aineistoksi ei ole kysymys pelkästään aineiston keruumetodin valinnasta. Ymmärrän lähestyväni ainakin oman sukupolveni kannalta uutta vuorovaikutuksen muotoa. Kirjoittamisen tavoista ainoastaan oma päiväkirja, yleisönosastokirjoittaminen ja aktiivinen tekstiviestimien ja sähköpostin käyttö ovat edeltäneet harjoittelualustoina tällaista mielipiteenilmaisua. Viestinnän tutkija Robert Arpo $(2005,279)$ näkee, että nettifoorumeilla vuorovaikutus toteutuu aiempien kommunikaatiomuotojen uudenlaisena yhdistelmänä. Erityisesti keskustelufoorumeilta 
löytyvälle aineistolle on ominaista puhekieltä muistuttava kirjoittaminen. Keski-ikää lähestyvillä tai sitäkin vanhemmilla keskustelijoilla vastaavista puhetilanteista lähimpänä ovat työpaikkojen ja lähibaarien taukotilakeskustelut, ohikulkijoiden mielipiteet ja käytäväkohtaamiset. Uutta hahmotettavaa tutkija kohtaa diginatiivien ${ }^{5}$ nettivuorovaikutuksessa. Siitä tuskin voi puhua enää aiempien kommunikaatiokokemusten soveltamisena ja erilaisten tietokonevälitteisten kanssakäymisen muotojen kirjokin on jo runsas.

Koska tässä artikkelissa huomio kohdistuu sananlaskujen ja niiden muunnosten käyttöön nettikeskusteluissa, on mahdollista tutkia myös perinteen välittymisen mekanismeja. Vaikka sananlaskujen kaltaisten ilmaisujen katsotaan parhaiten siirtyvän varhaisessa tunnevaltaisessa vuorovaikutuksessa, esimerkiksi isovanhemmilta arkisissa tilanteissa (Hain 1950; Prahlad 1996; Granbom-Herranen 2008), oletan, että nykyaikana tällaisten ilmaisujen hyvänä kasvualustana ovat juuri erilaiset internetin foorumit. Kuullen ymmärretty tai ainakin omaksuttu siirtyy kirjoitetun puheen kieleksi - ja luonnollisesti myös toiseen suuntaan. Virtuaalikontekstissa "kuultuina" sananlaskut elävät perinteenlajina uutta kehitysvaihetta.

Sananlaskujen voima on niiden tuttuudessa, vähintään rakenteen tutunomaisuudessa. Tunnistettavan sananlaskumuotin soveltaminen herättää tunteen puhujan ja kuulijoiden yhteisestä kielestä. Samalla kuulijalle tai lukijalle uusikin sananlaskumuoto houkuttaa hyväksymään osuvanoloisen väittämän. Amerikkalainen folkloristi Stephen D. Winick $(2003,573)$ pitää sananlaskumaisuuden tunnistamista samanvertaisena perinteen välittymisenä kuin aiemmin kokoelmiin kerättyjen ja tähän perinteenlajiin hyväksyttyjen sananlaskujen leviämistä.

Ihmisten tavat hahmottaa nettitilanne suhteessa aiempiin kommunikointikokemuksiinsa todennäköisesti vaihtelee. Käsitys siitä, onko kysymys julkisesta vai lähikontakteissa totutusta puheenpidosta, on varmasti erilainen omalla nimellään julkisesti esiintymään tottuneille kuin keittiönpöydän ääressä kommentoijille. Virallinen kirjeiden kirjoittaminen ei kuitenkaan ollut sähköpostikeksinnönkään alkusysäys. Kaikki alkoi laajalla työmaalla työskentelevien tutkijoiden tarpeesta kommunikoida keskenään. Kehiteltiin sähköisten viestien lähettäminen tietokonepäätteeltä toiselle. Internetin alkumuoto synnytti epämuodollisen sähköpostien kirjoittamiskäytännön. Keskeisintä oli nopea kommunikointi. (Wallace 1999, 62.) Näin nettikirjoittaminen on kaatanut perinteisen rajan tutuille ja vieraille tarkoitettujen viestien väliltä.

\section{Tapaus Sofi OKsanen valtalehden KESKUSTELUFOORUMILLA}

Tutkimusaineistoni koostuu kirjailija Sofi Oksaseen liittyvästä, Helsingin Sanomien

5 Diginatiivi on Marc Prenskyn (2001) käyttämä termi, joka kuvaa ensimmäistä sukupolvea, joka on syntynyt ja kasvanut digitaalisen tekniikan käyttämisen ympäristöön. 


\section{Outi Lauhakangas: Internetin keskustelufoorumit sananlaskujen kasvualustana}

sivuilla kesäkuussa 2010 käydystä nettikeskustelusta. Aineistoni synnyttäneen kysymyksen taustalta löytyy jo puolta vuotta aiemmin alkanut keskustelu. Marraskuun lopulla 2009 Helsingin Sanomien päivän kysymys ${ }^{6}$ oli "Mollataanko suomalaista miestä aiheetta?" Tähän äänestykseen osallistui yli 10000 vastaajaa, mikä on tuolla foorumilla suuri, mutta silti tavanomainen vastausmäärä. Klikkaamalla äänestäneistä vastasi kyllä $63 \%$ ja ei $37 \%$.

Äänestykseen liittyviä kommentteja ei ole enää saatavilla, mutta joka tapauksessa useimmat lukijat tiesivät kysymyksen liittyvän Finlandia-palkitun Sofi Oksasen esiintymiseen Tanskan televisiossa vuoden 2009 marraskuussa. "Tyypillisellä suomalaismiehellä ei ole kykyä kertoa tunteistaan ja sanojen sijasta hän käyttää väkivaltaa", Helsingin Sanomat siteerasi Oksasta. Ohjelmasta oli uutisoinut ensimmäisenä Iltalebti, jonka käsittelyssä lausunnot värittyivät ja kärjistyivät Suomi-kritiikiksi. HS kirjoitti 24.11.2009: "Finladia-palkittu kirjailija Sofi Oksanen arvostelee suorasanaisesti Suomea Tanskan televisiossa esitetyssä ohjelmassa. Kovaa kritiikkiä saavat muun muassa Oksasen väkivaltaisina pitämät suomalaismiehet sekä oikeusjärjestelmä, joka kirjailijan mielestä ei rankaise riittävästi kotiväkivallasta."

Ennen Helsingin Sanomien kesäkuiseen 'Päivän kysymykseen' liittyvää keskustelua, jonka valitsin artikkelini aineistoksi, Oksasen herätti jälleen huomiota annettuaan populaarille aikakauslehdelle haastattelun. Muutkin lehdet kommentoivat tätä haastattelua. Muiden muassa $H S: n$ toimittaja Esa Mäkinen (2010) raportoi:

Esimerkiksi toukokuun alussa julkaistussa $A p u$-lehdessä Oksanen sanoo WSOY:stä, että "etenkin käännös- ja markkinointitoiminta on täysin amatöörimäistä, pitää palkata joku, joka ne hoitaa". Lisäksi Oksanen toteaa, että "toimitusjohtajan puhelimeen voisi vastata vaikka apina, eivätkä asiat sujuisi paljon huonommin."

$H S$ :n uusi kysymys oli konkreettiseen tapahtumaan liittyvä ja koski Oksasen ja WSOY:n välirikkoa, joka johti kustantajan ilmoittamaan yhteistyön päättymiseen. Lehden provosoiva kysymys oli 16.6.2010:

Tekikö WSOY väärin antaessaan potkut Sofi Oksaselle?

WSOY ilmoitti eilen, ettei se jatkossa kustanna kirjailija Sofi Oksasen teoksia. Päätöstä on kummasteltu, sillä Oksasen Puhdistus-kirjaa on myyty 140000 kappaletta. Tekikö WSOY mielestäsi virheen?

6 Helsingin Sanomien 'Päivän kysymys' on lehden verkkosivulla kenen tahansa etulehdellä vierailijan vastattavissa. Se on muotoiltu jonkin ajankohtaisen uutisen pohjalta mahdollisimman yksinkertaiseksi. Äänestys tapahtuu yksinkertaisesti klikkaamalla eli hiiren painalluksella vihreän 'Kyllä'- tai punaisen 'Ei'-painikkeen kohdalla. Äänestys kestää päivittäin 00:00-16:30, mutta kommentoida voi jälkeenkin päin. Valintaa seuraa sivu, jossa on näkyvillä korkeintaan pari riviä lisätietoa ja vastausten jakauma graafisesti ja prosenttilukuina esitettynä. Lehti houkuttaa kävijää lukemaan lisää alla olevan linkin kautta. Näin edeten löytyy myös kommentointifoorumi. Öiseen aikaan kommentteja ei julkaista lainkaan, vaan ne odottavat jonossa aamuruuhkan purkua. 


\section{Outi Lauhakangas: Internetin keskustelufoorumit sananlaskujen kasvualustana}

Kun kysymyksen lukee lisäselityksineen, siinä pyydetään ottamaan joko-tai-kanta yhdellä kyllä- tai ei-klikkauksella sekä teon yleiseen oikeudenmukaisuuteen että järkevyyteen kustantajan kannalta katsoen. Tämä hämmentävä kaksinaisuus varmasti karkotti äänestäjiä, sillä tavanomaista äänestäjämäärää harvempi eli 2251 lukijaa osallistui klikkaamiseen puolen vuorokauden kuluessa. Joka tapauksessa äänestyskysymys antoi aiheen jatkaa nettifoorumilla kommentointia. Läpi yön ja seuraavan arkipäivän kertyi 348 perustelua ja lisäkommenttia, joissa esiintyi runsasta sananlaskujen käyttöä. Tosin moni äänestykseen vastannut keskustelija valitti kommentissaan vastaamisen mahdottomuutta taustatietojen puuttuessa. (Todennäköisesti tästä syystä Helsingin Sanomat on poistanut aiheen suosittuina arkistoitujen 'Päivän kysymysten' listalta.) "Kyllä, WSOY teki väärin/virheen", vastasi $43 \%$ ja hieman useamman eli $57 \%$ :n mielestä kustantaja ei tehnyt väärin/virhettä.

\section{KesKUSTELUFOORUMI NETIN TEKSTILAJINA}

Valitsemani Sofi-aineisto ${ }^{7}$ on ajallisesti ja kulttuurisesti tarkkarajainen ja tuore aineisto. Viestintäympäristö on hyvin erityinen, ja varmasti keskusteluun osallistuu enimmäkseen foorumin jo aiemmin tuntevia henkilöitä. Kulttuurisena kanssakäymisen muotona nettikommentointi on uutta, vaikka välineen uutuus on suhteellista sen mukaan, kuuluuko käyttäjä nettikommunikointia edeltävään vai diginatiiveiksi syntyneiden sukupolveen.

Verrattuna kasvotusten tai äänikontaktissa käytyyn keskusteluun nettivuorovaikutus perustuu vähintään kahteen vaihtoehtoiseen kommunikointitapaan. Siinä yhdistyvät seuraavat asiat: nopeus ja hitaus; spontaani reagointi ja verbaalinen pallottelu tai harkittu ja perusteltu vastaaminen; toisten mielipiteisiin paneutuminen tai yksisuuntainen mielipiteenilmaus. Väline tekee mahdolliseksi antaa välitöntä eli ensimmäisen mielijohteen herättämää palautetta tai vaihtoehtoisesti kirjoittaa muiden mielipiteisiin perehtyneen ja harkitun kommentin. Toisin kuin kasvokkaisissa puhetilanteissa se, millä tavoin - sujuvasti, takellellen, korjaillen, muista lähteistä lainaten - viesti kielellisesti syntyy ja muotoillaan, jää tilanteessa näkymättömiin.

Sofi-aineiston virittänyt 'Päivän kysymys' viittasi tällä kertaa suoraan nimettyyn julkisuuden henkilöön eli kirjailija Oksaseen ja lähes yllytti henkilöön kohdistuvaan kommentointiin. Foorumikirjoittajat päivittelivät runsaasti ja värikkäästi kirjailijan ulkonäköä, tekivät oletuksia luonteen, oletetun kansalaisuuden ja ilmiasun suhteesta ja puuttuivat varsinkin käytökseen, jota pidettin ylimielisenä. Silti osa keskustelijoista käytti hyväkseen tilaisuutta ottaa kantaa yleisemmin kirjailijoiden ja humanistien oikeuksiin. Osa muisti samaa kustantajaa koskevat aiemmat irtisanomisuutiset ja tivasi liiketoiminnan harjoittamisen pelinsääntöjä. Oletettavasti ainakin osa äänestykseen vastanneista vieraili foorumilla aktivoiduttuaan ottamaan juuri tähän asiaan periaatteellisesti kantaa.

7 Valitusta 16.6.2010 aikana kertyneestä 'Päivän kysymyksen' kommenteista koostuvasta nettiaineistosta käytetään artikkelissa nimitystä Sofi-aineisto. 


\section{SANANLASKUT JA SANANLASKUMUUNNOKSET NETTIFOORUMILLA}

Sananlaskuja ja sananlaskumaisia ilmaisuja käytettiin Sofi-aineistossa 72 kertaa 63:ssa kaikkiaan 344 kommentista. Osa kommentoijista käytti jopa kahta tai kolmea sananlaskumaista ilmausta repliikissään. Siis vastauksista 18 \% sisälsi vähintään yhden sananlaskun tai sananlaskuperäisen puheenparren. Tunnistin 46 erilaista sananlaskutyyppiä tai vakiintunutta ilmaisua, joista kuusi esiintyi vähintään kolme kertaa - suosituimmat 9 ja 7 kertaa. Yllättävää oli, että kahta kertaa esiintyviä sananlaskuja tai ilmauksia ei aineistossa ollut. Tästä voisi päätellä, että 'Päivän kysymyksen' tilanne hahmotettiin ainakin osittain yhteisin sosiaalisin välinein. Nuo kuusi toistuvaa ilmaisua toimivat puolesta-vastaan-kommentoinnin hallitsevina selityksinä. Tuloksia voisi jatkotutkimuksissa testata myös selvittämällä ilmaisujen yleistä suosiota nyky-Suomen nettiteksteissä.

On kiintoisaa miettiä, mistä kaikista aiemmista vuorovaikutuksen muodoista ja niissä kertyneistä kokemuksista ja käytänteistä otamme välineitä netissä kommunikoidessamme. Meksikolainen sosiolingvisti Elías Domínguez Barajas (2010), jolla on kognitiivinen lähestymistapa sananlaskuihin, pitää tätä genreä osoituksena ihmisen erityisestä taidosta käsitellä kohtaamiaan asioita mielensisäisesti. Domínguez Barajas tutkii sananlaskuja ja niiden käyttöä nimenomaan oman kulttuurinsa suullisen perinteen elinvoimaisena osana. Hän osoittaa, että sananlaskupuheen ja vuorovaikutuksen kautta opitut kognitiiviset taidot voivat siirtyä puheen alueelta kirjoittamisen vaatimaan prosessointiin.

Domínguez Barajas (2010, 63) horjuttaa käsitystä kirjallisen kulttuurin hegemoniasta ihmisen ainoana tienä kehittyä abstraktien asioiden käsittelyssä Puhekulttuurin ja kirjaviisauden välillä ei näin ollen ole kognitiiviselta kannalta kuin välineisiin perustuva ero. Myös psykolingvistit Raymond Gibbs ja Dinara Beitel ovat pohtineet kielen kuvallisuuden suhdetta käsitteellistävään ajatteluun. He näyttävät, että käsitteellistäminen on perustaltaan kuvallista. Erityisen ilmeistä on ihmisen taipumus ajatella konkreettisin metaforin varsinkin käsitellessään inhimillisiä tapahtumia. (Gibbs \& Beitel 1995, 110, 116, 129.)

Aiemmissa internethakujen avulla tekemissäni tutkimuksissa havaitsin, että sananlaskuja käytetään hyvin monenlaisissa yhteyksissä, mutta niiden käyttöä suositaan varsinkin pyrittäessä vaikuttamaan mielipiteisiin. Valitsemastani nettitekstiaineistosta en siis olettanutkaan löytäväni sananlaskujen sosiaalisen funktioiden koko skaalaa. Tutkiessani sananlaskumuotteja ${ }^{8}$ eli sananlaskujen yleisiä malleja tai vakiintuneita rakenteita suhteessa nettitekstien tekstilajeihin totesin, että esimerkiksi Parempi-alkuisia sananlaskuja tai tämän sananlaskumuotin mukaisia ilmaisuja ei sovelleta uutisoinnissa, tieto- tai tieteellisissä teksteissä. (Lauhakangas 2009c, 76.)

Leimallisesti mielipiteenilmaisuun liittyvänä ja tunteisiin vetoavana vakuuttelupuheena sananlaskumaisia ilmaisuja vältetään asiapainotteisissa tekstilajeissa, jotta luotaisiin

8 Matti Kuusen käyttämä käsite formula on lähimpänä valitsemaani muotin käsitettä. Kuusi kirjoitti: "Sananparsien historia on tärkeältä osaltaan syntyvien, muotiin tulevien ja muodista väistyvien sananparsiformulain historiaa" $(1954,141)$. 
tiedonvälityksen yhteyksiin kuuluvaa objektiivisuuden vaikutelmaa. Omin mielipitein toisten mielipiteisiin vaikuttamaan pyrkivä puhe ei kuitenkaan ole ainoa vakuuttelupuheen laji. Ryhmän hyväksyntää hakevassa ulkopuolista arvioivassa puheessa sananlasku voidaan tuoda ikään kuin vastaansanomattomana yleistyksenä, yhteenvetona jo muiden käymälle ajatusten vaihdolle. (Lauhakangas 2004, 184; Penfield 1983, 59.)

\section{Puolesta tai vastaAn -Kannanoton Perustelutarve}

Sananlaskut eivät sinänsä ole negatiivisia tai positiivisia, vaikka yhteydestään irrallaan tarkasteltuna niistä näin voisi olettaa. Sananlaskujen totuusarvoa ei mitata, mutta niiden sosiaalinen toimivuus tilanteiden ja elämän ilmiöiden selittäjinä vahvistaa niiden uskottavuutta (Cram 1994 [1983], 90; Lauhakangas 2004, 72). Helposti hyväksyttävät analogiat vetoavat tehokkaammin kuin totuutta haparoivat ilmaisut keskustelutilanteissa, joissa läsnäolijoilla ei ole käsiteltävästä asiasta varmaa tietoa. Monitulkintaisuuden potentiaalin osoittaa myös Sofi-aineisto. Sananlaskua voi käyttää niin moneen tarkoitukseen ja kehystää eri tavoin. Juuri siihen monen ilmaisun säilyvyys ja levinneisyys perustuukin.

Jos Sofi-aineiston kommentit käynnistänyttä kysymysärsykettä analysoi sananlaskujen käyttöalttiuden kannalta, siitä voi tunnistaa useita yllykkeitä. Sanavalinnat ovat tarkoituksellisen provosoivia: viitataan vääryyden tekoon, puhutaan potkuista. Tarkoitus on herättää voimakkaita tunteita kaksijakoisesti puolesta tai vastaan. Sananlaskun tuominen puhetilanteisiin liittyykin useimmiten sosiaalisen jännitteen laukaisu- tai käsittelytarpeeseen. (Lauhakangas 2004.) Jos tosiasiatiedot ovat niukkoja ja tapahtumien kulku epäselvä, ihminen tekee päätelmiä aiempien kokemustensa ja asenteidensa varassa.

'Päivän kysymys' -aineiston sananlaskuja sisältävistä kommenteista $43 \%$ arvosteli joko avoimesti tai epäsuorasti Sofin käytöstä. Vain muutama sananlaskua käyttänyt kommentoija asettui Sofin puolelle. Yleisempää oli kääntyä haukkumaan vastapuolta, kuten kustannustaloa arvosteleva nimimerkki 'pitkä miinus pöljä pöljä’: "Teki. Se koira älähtääjohon kalikk. a kalabtaa...", tai nimimerkki' 'euroja', joka tarkastelee tilannetta etäältä ja esittää ennustuksen: "Ehkäpä Sofi astui jonkun varpaille, jonka itsetunto ei ollut riittävän vahva. WSOY:n siinä tulee loppujen lopuksi kärsimään. 'Paha saa aina palkkkansa." 'Tulkitsen suhteellisen neutraaliksi esimerkiksi 'Mollan' kommentin: 'Ei. Sofilta on unohtunut että sen lauluja laulat kenen leipää syöt'. Vaikka hän on äänestänyt ikään kuin WSOY:n ratkaisua ymmärtäen, perustelussa on yleistävä "sellaista elämä on" sävy. Sen sijaan 'torres' kohdistaa Sofiin avointa halveksuntaa: "Sen edestään kobtaa, minkä taakse jättää.' Sofi on ihan ällö, sai mitä ansaitsi'. Kokonaisen sananlaskujen avulla rakennetun tilannekuvauksen antaa 'Ukkeli ilman kuulokojetta'. Anonyyminäkin hän haluaa luoda itselleen tällä foorumilla iän ja kansanviisauksien vakuuttaman identiteetin tai statuksen.

"Ämmillä meni sukset ristiin, toinen voitti, mutta kumpi? Dïvalla on diivan elkeet ja jos alahuuli on pidempi kuin ylähuuli, niin siitä joutuu kärsimään, samoin tybmästä päästä kärsii koko kroppa. On tapahtunut kapillaari-ilmiö eli se aines, joka valuu normaalisti alapäästä ulos onkin noussut nyt ylös. Jos koira puree isäntänsä kättä, se voi saada menolipun Moskovaan, slobo horo." 
Pelkkä kyllä-ei-mielipide, olipa se oma tai toisen esittämä, herättää tarpeen selittää tai perustella. Yli puolet sananlaskua käyttäneistä kommentoijista - joista siis suuri osa oli äänestänyt kustantajan ratkaisua oikeutetuksi - perusteli äänestysklikkaustaan puuttumatta voimakkaasti Sofin persoonaan ja yleistämällä tilanteen. Esimerkiksi 'Elämä jatkuu' kirjoitti: "Nuori Diiva vastaan WSOY. Pätäkkää oleva kustantaja pisti pelinpoikki oikein tai väärin, vanhan surma on unden rahoittajan ilo." Suoranaisesti tilanteen kaksijakoisuutta kuvaava sananlasku nousi vain yhden kommentaattorin mieleen. 'Roopen' perustelussa kuuluu kunnioitus arvovaltaista vanhaa kustannustaloa kohtaan, mutta samalla varovainen huomautus: "Varmaan päätöstä on huolellisesti harkittu koska ei tämän hetken menestyneintä kirjailijaa muuten olisi erotettu. Toisaalta mitalilla on aina kaksi puolta eli WSOYn johdossa on keskustelun paikka.” Pohdiskeleva varovaisuus nettifoorumilla tuntuu heijastelevan ihmisten oman tilanteen suhteuttamista uutiseen. Jyrkän mielipiteen ilmaisun sijaan ikään kuin harjoitellaan työelämän vaatimuksiin sopeutumista. Nimimerkki 'Ehkä parempi näin?' pohtii kello yhdeksältä aamulla näin:

Voi olla niinkin, että Oksasen menestyskirjat on kirjoitettu, jatkossa ei tule enää yhtä myyviä kirjoja. Onhan tämä "riman ylitys" monelle taiteen tekijälle aina ollut kauhun paikka...miten saan vielä paremman kirjan/ laulun/sävellyksen... Ehkä taustalla on niin isot "erimielisyydet" että Otava katsoi, että parempi näin, hoidetaan "kerta rutina kuin jatkuva kitinä". Niinhän se on työelämässä yleensäkin, jos siellä ei "skulaa" joka tasolla, siihen loppuu hommat. Ehkä Oksanen lähti leijailemaan "sfääreihin" ja ...tulee sieltä rytinällä alas. Onhan olemassa hyvä sanonta: Kun olet matkalla "ylös", ole ystävällinen niille ihmisille, joiden kanssa toimit, sillä tarvitset niitä ibmisiä kun tulet "alas".

\section{SANANLASKumuUnNosten osuUs Sofi-AINEISTOSSA}

Sananlaskujen nettitutkimuksen kannalta olen pitänyt muunnosten ja niin sanottujen antisananlaskujen sosiaalisten funktioiden analysointia keskeisenä. Jatkoin väitöskirjani (2004) virittämää kysymystä sananlaskumaisten ilmausten tehtävistä sosiaalisessa vuorovaikutuksessa 2007 kirjoittamassani artikkelissa. Jo Matti Kuusi kirjoitti kiinnostuksestaan uusiin sananparsikehitelmiin, että "iskulauseiden ja sananparsien synnyn, leviämisen ja tyylikeinojen problematiikka on melkoiselta osalta sama" $(1954,9)$. Sananlaskumuunnosten käyttö näkyy jatkavan nykykulttuurissa perinteisten sananlaskujen tapaan sekä sosiaalisten taitojen soveltamista että luonnollistavien perustelujen tuomista omien havaintojen tai mielipiteiden tueksi (Lauhakangas 2004, 129-260). Aiemmat kokeiluni lähestyä internetin tekstimassaa sananlaskumuottien eli tuttujen sananlaskutekstien rakenteesta valittujen hakusanojen avulla osoittivat, että sananlaskuja ja niiden muunnoksia käytetään runsaasti. (Lauhakangas 2009b; 2009c)

Minulle olikin yllätys, että Sofi-aineistossa perinteisten sananlaskujen osuus oli selkeästi suurempi kuin sananlaskumukaelmien. Vaikuttiko ehkä aihe tai halu vaikuttaa toisten mielipiteisiin siihen, että kielellä leikittely jäi toissijaiseksi? 


\section{Outi Lauhakangas: Internetin keskustelufoorumit sananlaskujen kasvualustana}

Jatkoanalyysin paikka olisi selvittää, onko valitsemassani mielipideaineistossa erityisen vähän muunnoksia tai sananlaskuparodioita muilta nettifoorumeilta kerättäviin aineistoiihin verrattuna. Sofi-aineistossa ainoastaan yksi ilmaus on selkeästi nurin käännetty eli anti-sananlasku: Ei osaavalle töitä löydy. Huumoria taas viljelee kehitelmä Jos koira puree isäntänsä kättä, se voi saada menolipun Moskovaan. Varsinaisia sanaleikkejä ei esiinny. Luovaa sananlaskumuotin soveltamista ovat vaatineet seuraavat kaksi esimerkkiä. Ei ykesi räksyttävä akeka paljon heiluttele liikevaibtoa, jossa sananlaskumuottina on vakiintunut alku Ei y/esi... Toisen alkuperä aukenee vain niille, joiden sananlaskurepertuaariin kuuluu sääsananlasku Uusi lumi on vanhan surma. > Vanhan surma on unden rahoittajan ilo.

Useimmiten muunnos on yhden tai kahden sanan vaihto, jatke tai jatkeen pois jättäminen eli ikään kuin varmistus idean ymmärretyksi tulemisesta:

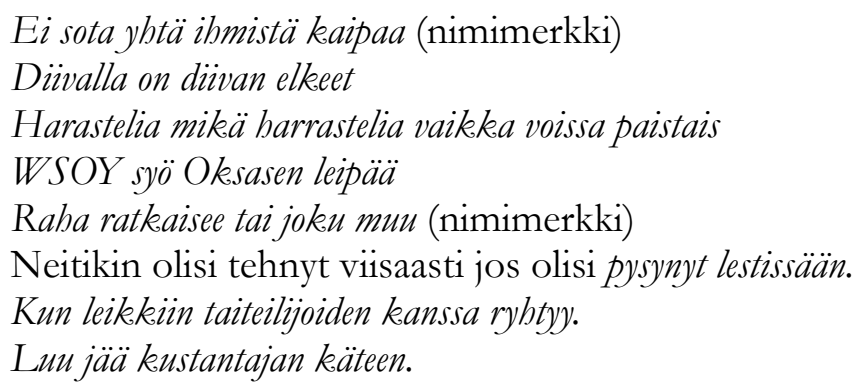

\section{SOFI-AINEISTON SANANLASKUJEN TEMATIIKKA}

Taustaa sananlaskujen käytön syiden pohdintaan antaa niiden tematiikan tarkastelu. Tässä ilmaukset on irrotettu välittömistä tekstiyhteyksistään. Sen sijaan tieto yleisestä kommentointikontekstista ja yhteisestä kysymysärsykkeestä tekee vertailusta mielenkiintoisen.

Taulukossa 1 on esitetty kaikki ne sananlaskut ja sananlaskumuunnokset, jotka on löydettävissä kansainvälisestä Matti Kuusi sananlaskutietokannasta ${ }^{9}$ (Lauhakangas 2001).

\begin{tabular}{|l|l|l|}
\hline Lainaukset nettikommenteista & Sananlaskutyyppi & M6-ryhmä ja tyyppinumero \\
\hline $\begin{array}{l}\text { vanhan surma on uuden } \\
\text { rahoittajan ilo. }\end{array}$ & $\begin{array}{l}\text { Uusi lumi on vanhan lumen } \\
\text { surma. (Laukkanen \& } \\
\text { Hakamies 1984) }\end{array}$ & $\begin{array}{l}\text { A3c kevät : syksy / kesä : talvi } \\
\text { / vuosi ja vuodentulo }\end{array}$ \\
\hline Diivalla on diivan elkeet & Koiralla on koiran metkut & $\begin{array}{l}\text { C1a 34 X:n perusluonto } \\
\text { pysyy /perustuntomerkit eivät } \\
\text { muutettavissa }\end{array}$ \\
\hline
\end{tabular}

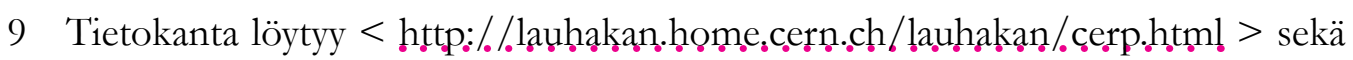
<w.www.finlitit.fi > sivuston kautta. 
Outi Lauhakangas: Internetin keskustelufoorumit sananlaskujen kasvualustana

\begin{tabular}{|c|c|c|}
\hline $\begin{array}{l}\text { harrastelia mikä harrastelia } \\
\text { vaikka voissa paistais }\end{array}$ & $\begin{array}{l}\text { Ryssä on ryssä vaikka voissa } \\
\text { paistais }\end{array}$ & C1b $31 \mathrm{X}$ on aina $\mathrm{X}$, vaikka... \\
\hline Niin makaa kuin petaa & Niin makaa kuin petaa & $\begin{array}{l}\text { C2c } 14 \text { X-toiminta /työ } \\
\text { tuottaa X-tuloksen /-palkan/- } \\
\text { rangaistuksen/-seurauksen }\end{array}$ \\
\hline $\begin{array}{l}\text { ei yksi räksyttävä akka paljon } \\
\text { heiluttele liikevaihtoa }\end{array}$ & $\begin{array}{l}\text { (C4a 12e Ei yksi pyssy kauas } \\
\text { pyljy) }\end{array}$ & $\begin{array}{l}\text { C4a pieni/yksi ei ole tai } \\
\text { tule suureksi / yksi on } \\
\text { kokonaisuudelle merkityksetön }\end{array}$ \\
\hline $\begin{array}{l}\text { iso melu nyt vaan on nostettu } \\
\text { "tyhjästä" }\end{array}$ & Paljon melua tyhjästä & $\begin{array}{l}\text { C4e } 14 \text { mitätön alku tai syy - } \\
\text { suuri vaikutus tai reaktio }\end{array}$ \\
\hline $\begin{array}{l}\text { Liekö karvoihin katsomista } \\
\text { (nimimerkki) }\end{array}$ & $\begin{array}{l}\text { Ei ole koiraa karvoihin } \\
\text { katsomista }\end{array}$ & $\begin{array}{l}\text { C6d } 15 \text { ulkomuoto } \\
\text { (musta:valkea) < työkunto / } \\
\text { ravintoarvo /jne. }\end{array}$ \\
\hline $\begin{array}{l}\text { Aina ei voi saada sitä mitä } \\
\text { haluaa }\end{array}$ & Ei katti kaikkea saa mitä tahtoo & $\begin{array}{l}\text { D3h } 19 \text { kyltymätön ahneus vie } \\
\text { pettymyksiin }\end{array}$ \\
\hline $\begin{array}{l}\text { Yksi ihminen on saman } \\
\text { arvoinen kuin toinen }\end{array}$ & $\begin{array}{l}\text { (Kaikkien päällä päivä paistaa) } \\
\text { Ei yksi oo paree kun toinenkaa } \\
\text { eikä aina niinkää hyvä. } \\
\text { (Laukkanen \& Hakamies 1984) }\end{array}$ & $\begin{array}{l}\text { E1g } 12 \text { ihmisten (luonnon) } \\
\text { yhtäläinen alkuperä / arvo ja } \\
\text { perusoikeudet }\end{array}$ \\
\hline Ei kukaan ole korvaamaton & $\begin{array}{l}\text { Kukaan ei ole korvaamaton. } \\
\text { (Kuusi 1988) }\end{array}$ & $\begin{array}{l}\text { E1g } 12 \text { ihmisten (luonnon) } \\
\text { yhtäläinen alkuperä / arvo ja } \\
\text { perusoikeudet }\end{array}$ \\
\hline $\begin{array}{l}\text { Se joka kuuseen kurkottaa, se } \\
\text { katajaan kapsahtaa }\end{array}$ & $\begin{array}{l}\text { Kuuseen kurkottaa, katajaan } \\
\text { kapsahtaa }\end{array}$ & $\begin{array}{l}\text { E1j } 29 \text { keskitien viisaus / } \\
\text { liioittelun ja äärimmäisyyksien } \\
\text { karttaminen / kompromissien } \\
\text { suosittelu }\end{array}$ \\
\hline mitalilla on aina kaksi puolta & Mitalilla on kaksi puolta & $\begin{array}{l}\text { E1k } 13 \text { asiat eri näkökulmista } \\
\text { erilaisia // onni } \\
\text { onnettomuudessa -paradokseja }\end{array}$ \\
\hline $\begin{array}{l}\text { sitä saa, mitä tilaa. } \\
\text { sitä saa mitä tilaa } \\
\text { sai mitä tilasi } \\
\text { saa mitä tilaa! } \\
\text { sitä saa mitä tilaa } \\
\end{array}$ & $\begin{array}{l}\text { Sitä saa, mitä tilaa. (Kuusi } \\
\text { 1988) }\end{array}$ & $\begin{array}{l}\text { F1b paha /synti / petollinen } \\
\text { joutuu häpeään / saa } \\
\text { rangaistuksen : rehellisyys } \\
\text { palkitaan }\end{array}$ \\
\hline Paha saa aina palkkansa & $\begin{array}{l}\text { Hyvä ja paha saa aina palkkansa } \\
\text { (Raamattu, Sananlaskut 11:21) }\end{array}$ & $\begin{array}{l}\text { F1b 18b paha / synti / } \\
\text { petollinen joutuu häpeään / } \\
\text { saa rangaistuksen : rehellisyys } \\
\text { palkitaan }\end{array}$ \\
\hline $\begin{array}{l}\text { Kyllä maailma opettaa yli- } \\
\text { ihmisetkin. }\end{array}$ & $\begin{array}{l}\text { Kyllä maailma opettaa, jos ei } \\
\text { muuta niin hiljaa kulkemaan }\end{array}$ & G6e $31 \mathrm{~b}$ vanhuuden vaivat \\
\hline $\begin{array}{l}\text { (parempi) kerta rutina kuin } \\
\text { jatkuva kitinä }\end{array}$ & $\begin{array}{l}\text { Parempi kultainen kuolema } \\
\text { kuin kituva elämä }\end{array}$ & $\begin{array}{l}\text { G7e } 11 \text { elämän ja kuoleman } \\
\text { rajalla (kituminen) }\end{array}$ \\
\hline $\begin{array}{l}\text { Pitää katsoa peilii jos ei pärjää } \\
\text { ihmisten kanssa } \\
\text { Katsoisi Oksanen peiliin } \\
\text { Katsokoon daami peiliin. } \\
\text { kenen pitää katsoa peiliin } \\
\text { kattokoot peiliin }\end{array}$ & $\begin{array}{l}\text { (Tunne itsesi ja kehrää } \\
\text { rohtimesi) }\end{array}$ & $\begin{array}{l}\text { H1b } 15 \text { itsetuntemuksen puute } \\
\text { - toisten kritisointi }\end{array}$ \\
\hline
\end{tabular}


Outi Lauhakangas: Internetin keskustelufoorumit sananlaskujen kasvualustana

\begin{tabular}{|c|c|c|}
\hline $\begin{array}{l}\text { Sitä kuusta kuuleminen, jonka } \\
\text { juurella asunto. }\end{array}$ & $\begin{array}{l}\text { Sitä kuusta kuuleminen, jonka } \\
\text { juurella asunto }\end{array}$ & $\begin{array}{l}\text { H3a } 10 \text { omien puolesta on } \\
\text { toimittava solidaarisesti }\end{array}$ \\
\hline oman pesän likaajia & Paha lintu pesänsä likaa & $\begin{array}{l}\text { H3d } 11 \text { kotipiiriä ja läheisiä } \\
\text { ihmisiä ei saa loukata }\end{array}$ \\
\hline Likapyykki pestään kotona. & Likapyykki on pestävä kotona & $\begin{array}{l}\text { H3d } 15 \text { kotipiiriä ja läheisiä } \\
\text { ihmisiä ei saa loukata }\end{array}$ \\
\hline $\begin{array}{l}\text { Ei sota yhtä ihmistä kaipaa } \\
\text { (nimimerkki) }\end{array}$ & Ei sota yhtä miestä kaipaa & $\begin{array}{l}\text { H3h } 10 \text { yksilö yhteisön } \\
\text { kannalta merkityksetön }\end{array}$ \\
\hline $\begin{array}{l}\text { Kun olet matkalla "ylös", ole } \\
\text { ystävällinen niille ihmisille, } \\
\text { joiden kanssa toimit, sillä } \\
\text { tarvitset niitä ihmisiä kun tulet } \\
\text { "alas" }\end{array}$ & $\begin{array}{l}\text { Joka toista auttaa, sitä itseään } \\
\text { autetaan }\end{array}$ & $\begin{array}{l}\text { H5d 09fvastavuoroisuus / } \\
\text { toisen kohteleminen ennustaa } \\
\text { itse saadun kohtelun }\end{array}$ \\
\hline $\begin{array}{l}\text { kun leikkiin taiteilijoiden kanssa } \\
\text { ryhtyy. }\end{array}$ & $\begin{array}{l}\text { Joka leikkiin rupee, se leikin } \\
\text { kestää }\end{array}$ & $\begin{array}{l}\text { H7g } 19 \text { maltti / oman } \\
\text { aggression peittäminen }\end{array}$ \\
\hline $\begin{array}{l}\text { Kyllä puhetta maailmaan } \\
\text { mahtuu. }\end{array}$ & Kyllä maailma ääntä vetää & $\begin{array}{l}\text { J1o } 26 \text { sana on vapaa / kaikkia } \\
\text { puheita ei pidä ottaa täydestä }\end{array}$ \\
\hline $\begin{array}{l}\text { Tunkiolle mahtuu vain yksi } \\
\text { kana. }\end{array}$ & Kaksi kukkoa yhdellä tunkiolla & $\begin{array}{l}\text { K1c } 13 \text { kaksi päällikköä / } \\
\text { herraa ei sovi yhteen }\end{array}$ \\
\hline $\begin{array}{l}\text { - Lopettivat - idiootit - lypsävän } \\
\text { lehmän. } \\
\text { - Tuskin kustantaja kovin } \\
\text { heppoisin perustein hyvin } \\
\text { lypsävää lehmää lopettaisi. }\end{array}$ & $\begin{array}{l}\text { Parempi lehmä lypsää kuin } \\
\text { tappaa. }\end{array}$ & $\begin{array}{l}\text { K1e } 13 \text { alaisen kohtelun } \\
\text { strategiaa / suostuttelu } \\
\text { kannattaa }\end{array}$ \\
\hline $\begin{array}{l}\text { - tuskin kultamunia munivaa } \\
\text { kanaa pienestä syystä } \\
\text { ulosheitetään kanalasta. } \\
\text { - Jotain hämminkiähän siellä } \\
\text { ilmeisesti on kun tuollainen } \\
\text { kultakala potkaistaan pois } \\
\text { - Ehdottomasti kultamunan } \\
\text { kadottivat } \\
\text { - Kuristivat kultamunia } \\
\text { munivan hanhen. Puupäät. } \\
\text { - hölmöä herkkänahkaisuutta } \\
\text { heittää muniva kana pihalle. } \\
\text { - Kenen kunniaan kolahti niin, } \\
\text { että pitää päästää vapaaksi } \\
\text { kultamunia muniva lintu? } \\
\text { - Tämäpä se juuri todistaa että } \\
\text { johto ei ole tehtäviensä tasalla, } \\
\text { kun kultamunivan kanasen } \\
\text { potkaisi pellolle. }\end{array}$ & $\begin{array}{l}\text { Ei pidä tappaa kultamunia } \\
\text { munivaa kanaa. }\end{array}$ & $\begin{array}{l}\text { K1e } 14 \text { alaisen kohtelun } \\
\text { strategiaa / suostuttelu } \\
\text { kannattaa }\end{array}$ \\
\hline $\begin{array}{l}\text { sen lauluja laulat kenen leipää } \\
\text { syöt } \\
\text { WSOY syö Oksasen leipää, } \\
\end{array}$ & $\begin{array}{l}\text { Jonka leipää syödään, sen virttä } \\
\text { lauletaan }\end{array}$ & $\begin{array}{l}\text { K1g } 18 \text { alamaisuuden normeja } \\
\text { ja strategiaa }\end{array}$ \\
\hline
\end{tabular}




\section{Outi Lauhakangas: Internetin keskustelufoorumit sananlaskujen kasvualustana}

\begin{tabular}{|c|c|c|}
\hline $\begin{array}{l}\text { - ei kannattais purra sitä kättä } \\
\text { mikä syöttää. } \\
\text { - Ei koirakaan murise } \\
\text { ruokkivalle kädelle. } \\
\text { - Jos koira puree isäntänsä } \\
\text { kättä, se voi saada menolipun } \\
\text { Moskovaan } \\
\text { - Don’t bite the hand that } \\
\text { feeds you. } \\
\text { - tyhmä että haukkuu sitä } \\
\text { kenen leipää syö.' } \\
\text { - Ei passaa tölviä leivänantajaa } \\
\text { - On tyhmää purra ruokkivaa } \\
\text { kättä. }\end{array}$ & $\begin{array}{l}\text { Ei koirakaan isäntäänsä hauku/ } \\
\text { pure }\end{array}$ & $\begin{array}{l}\text { K1g } 21 \text { alamaisuuden normeja } \\
\text { ja strategiaa }\end{array}$ \\
\hline Häntä heiluttaa koiraa & (Ei häntä anna käskyjä päälle) & $\begin{array}{l}\text { K1j } 14 \text { väärä ja oikea } \\
\text { sosiaalinen järjestys }\end{array}$ \\
\hline $\begin{array}{l}\text { Neitikin olisi tehnyt viisaasti jos } \\
\text { olisi pysynyt lestissään. }\end{array}$ & Pysyköön suutari lestissään & $\begin{array}{l}\text { K1j } 23 \text { väärä ja oikea } \\
\text { sosiaalinen järjestys }\end{array}$ \\
\hline $\begin{array}{l}\text { Raha ratkaisee tai joku muu } \\
\text { (nimimerkki) }\end{array}$ & Raha se on joka ratkaisee & $\begin{array}{l}\text { K2a } 21 \text { rahalla saa kaikkea } \\
\text { - tavaraa / ruokaa /valtaa / } \\
\text { pääsyn minne tahansa }\end{array}$ \\
\hline luu jää kustantajan käteen. & Luu jakajan käteen & $\begin{array}{l}\text { L1c } 11 \text { luontaisoikeudet / } \\
\text { omistus- ja rauhoitusnormeja }\end{array}$ \\
\hline $\begin{array}{l}\text { Se koira älähtää johon kalikka } \\
\text { kalahtaa. }\end{array}$ & $\begin{array}{l}\text { Se koira älähtää, johon kalikka } \\
\text { kalahtaa }\end{array}$ & $\begin{array}{l}\text { L1e } 10 \text { rikos / syyllisyys } \\
\text { paljastuu ja johtaa } \\
\text { rangaistukseen }\end{array}$ \\
\hline $\begin{array}{l}\text { ei voi kauhalla vaatia, kun on } \\
\text { vain pikkulusikalla annettu. }\end{array}$ & $\begin{array}{l}\text { Siltä ei sovi kauhalla vaatia, } \\
\text { jolle on lusikalla annettu. } \\
\text { (Laukkanen \& Hakamies 1984) }\end{array}$ & M3c tyhmä ei tajua eikä näe \\
\hline Näitä kyllä riittää. & $\begin{array}{l}\text { Hullui niitä riittää viisahien } \\
\text { pään ajaksi, ja metsähullut } \\
\text { ne ovat viellä erikseen. } \\
\text { Kuolemajärvi (Laukkanen \& } \\
\text { Hakamies 1984) } \\
\text { Ei hulluja kylvetä eikä kynnetä, } \\
\text { itsestään... (M3c 11) }\end{array}$ & M3c tyhmä ei tajua eikä näe \\
\hline $\begin{array}{l}\text { tyhmästä päästä kärsii koko } \\
\text { kroppa }\end{array}$ & $\begin{array}{l}\text { Tyhmästä päästä kärsii koko } \\
\text { ruumis }\end{array}$ & $\begin{array}{l}\text { M3d } 29 \text { tyhmä toimii } \\
\text { nurinkurisesti / omaksi } \\
\text { vahingokseen }\end{array}$ \\
\hline $\begin{array}{l}\text { näin käy kun rupeaa } \\
\text { polttelemaan siltoja takanaan. }\end{array}$ & polttaa kaikki sillat takaansa & $\begin{array}{l}\text { M4a } 11 \text { rohkeus / riskinotto } \\
\text { / pelottomuus on tuoton/ } \\
\text { tavoitteen saavuttamisen } \\
\text { edellytys }\end{array}$ \\
\hline ei osaavalle töitä löydy. & (Ei kätevä köyhdy) & $\begin{array}{l}\text { M5a taito / ammattitaito - } \\
\text { taitava ja huono työntekijä }\end{array}$ \\
\hline tulos tai ulos. & $\begin{array}{l}\text { (Joka ei tahdo työtä tehdä, ei } \\
\text { saa syödäkään) }\end{array}$ & $\begin{array}{l}\text { M7a ahkeruus /vaivannäkö } \\
\text { palkitaan / / laiska jää(köön) } \\
\text { ruuatta }\end{array}$ \\
\hline
\end{tabular}


Outi Lauhakangas: Internetin keskustelufoorumit sananlaskujen kasvualustana

\begin{tabular}{|l|l|l|}
\hline $\begin{array}{l}\text { Sen edestään kohtaa, minkä } \\
\text { taakse jättää. }\end{array}$ & $\begin{array}{l}\text { Minkä taakseen panee, sen } \\
\text { edestään löytää }\end{array}$ & $\begin{array}{l}\text { M8a 28 pikkutarkka } \\
\text { taloudellisuus / } \\
\text { talonpoikaisasketismi }\end{array}$ \\
\hline nuorena se on vitsa väännettävä & Nuorena vitsa väännettävä & $\begin{array}{l}\text { T1b 20 kaikella (eri töillä, } \\
\text { materiaaleilla) on oikea aikansa } \\
\text { (ajoitus) }\end{array}$ \\
\hline Pulinat pois. & $\begin{array}{l}\text { (T1e 42 Joka jälkineuvon } \\
\text { kanssa tulee, pitää hirtettämän) }\end{array}$ & $\begin{array}{l}\text { T1e myöhästynyt } \\
\text { liikkeellelähtö/apu tai neuvo } \\
\text { vie vaikeuksiin/ on arvoton }\end{array}$ \\
\hline $\begin{array}{l}\text { Aika näyttää. } \\
\text { Aika näyttää... }\end{array}$ & $\begin{array}{l}\text { T1h 21 kannattaa odottaa } \\
\text { Aarempaa ajankohtaa - neuvo } \\
\text { löytyy, asiat ratkeavat }\end{array}$ \\
\hline Aika aikaansa kutakin. & $\begin{array}{l}\text { Aika aikaansa kutakin, sanoi } \\
\text { pässi kun päätä leikattiin. } \\
\text { (sanomus) }\end{array}$ & $\begin{array}{l}\text { T2a 10 aika muuttuu - uusi } \\
\text { vanhenee ja kuluu }\end{array}$ \\
\hline Elämä jatkuu (nimimerä) & $\begin{array}{l}\text { Niin kauan on toivoa kuin on } \\
\text { elämää) }\end{array}$ & $\begin{array}{l}\text { T3c tulevaan uskominen / } \\
\text { varautuminen / haaveilu / } \\
\text { toiveikkuus - pessimismi }\end{array}$ \\
\hline
\end{tabular}

Taulukko 1.41:Ile Sofi Oksastaja WSOY:tä koskevan nettiaineiston sananlaskulle löytyy selvä vastine kansainvälisestä Matti Kuusi sananlaskujen tyyppiluettelosta. Täydennykset kokoelmista Laukkanen \& Hakamies (1984) ja Kuusi (1988). Suluissa idealtaan samankaltainen sananlaskutyyppi.

Taulukosta 1 selviää, että Sofi-aineiston sananlaskuissa esiintyy monipuolisesti tälle genrelle tunnusomaista tematiikkaa. Tämä jo kertoo sen, että sama lähtökohta ei suinkaan herätä kaikissa niissäkään, joilla on kyky ja tarve käyttää sananlaskuja, samoja assosiaatioita. Samankin sananlaskun merkitys on käyttäjälleen tai kuulijalleen viime kädessä persoonallinen ja erilaisten kokemusten tulos. Sitä paitsi sama ihminen voi käyttää samaa sananlaskua hyvin erilaisissa tilanteissa. (Lauhakangas 2004, 258-259; Seitel 1977, 79; Yankah 1989.)

Silti on mahdollista löytää myös yhdenmukaisuutta 'Päivän kysymyksen' herättämissä sananlaskuassosiaatioissa. Sekä alaisen kohtelun että alamaisuuden strategian tyyppiryhmät K1 e ja K1g korostuvat. Samansuuntaista valtasuhteen hyväksyntää kuin $\mathrm{K} 1 \mathrm{~g}$ edustaa sosiaalisen järjestyksen ryhmä $\mathrm{K} 1 \mathrm{j}$ ja rahan kaikkivoipaisuuden ryhmä K2a. Myös C-ryhmä eli common sense -päättely tai sosio-logiikka (kuten X on aina X, vaikka...) on vahvasti edustettuna. Oma nykyajatteluun ilmeisesti istuva suosikkinsa on F1b-ryhmään (paha saa rangaistuksen) sijoitettu Sitä saa mitä tilaa. Se voisi yhtä hyvin olla samassa ryhmässä kuin Niin makaa kuin petaa (C2, X-toiminta tuottaa X-tuloksen). Myös aikaan ja sen parantavaan voimaan (T-ryhmät) luottaminen toistuu aineistossa.

Aineistossa on joukko uudempaa sananparsistoa: Elämä jatkun, Tulos tai ulos, Ei kukaan ole korvaamaton, Pulinat pois, Häntä heiluttaa koiraa, Nä̈tä kyllä riittää. Vaikka ne eivät aivan sellaisinaan esiinny kansainvälisessä sananlaskuluokituksessa, niille oli suhteellisen helppo löytää tyyppiryhmänsä ja ottaa ne mukaan temaattiseen tarkasteluun. Nämä slogaanit ovat suomalaiseen kielenkäyttöön vakiintuneita, ja pari niistä on noussut aikanaan suosioon tunnettujen poliitikkojen soveltamina. Pulinat pois! 


\section{Outi Lauhakangas: Internetin keskustelufoorumit sananlaskujen kasvualustana}

muistetaan Johannes Virolaisen tokaisusta: "Kansa on pubunut, pulinat pois!' Presidentti Mauno Koivisto taas käytti muunnosta sanonnasta Häntä heiluttaa koiraa. Hän sanoi ydinvoimalan rakentamista koskevasta kilpailusta 1968: "Jos yritämme pistää suurvallat keskenään kilpailemaan, jos me yritämme heilutella asioita, niin ne asiat alkavat heilutella meitä” (Virkkunen 1974, 30).

\section{KOMMENTTIEN SUOSITUIN SANANLASKUTYYPPI}

Useimmin mieliin noussut tilanteen luonnehdinta kommenttiaineiston 46 erilaisen sananlaskun tai vastaavan ilmaisun joukossa oli kultamunan, munivan kanan tai jopa kultakalan kadottaminen (7 kertaa) ja kaksi samaan sarjaan kuuluvaa viittausta lypsävän lehmän tappamiseen. Näissä korostettiin kustantajan tekemää virhettä tai väärää ratkaisua.

M6-sananlaskutietokannassa eli kansainvälisessä Matti Kuusi -sananlaskuluokituksessa (Lauhakangas 2001) tämä sananlasku on eurooppalaisessa muodossaan K1e 14 Ei pidä tappaa kultamunia munivaa kanaa. Samasta ryhmästä löytyy numero 13 Parempi lehmä lypsää kuin tappaa. Ryhmän otsikko on 'alaisen kohtelun strategiaa / suostuttelu kannattaa' ja se kuuluu pääryhmään 'sosiaalinen asema'.

Seuraavassa esitetään kultamuna-aiheiset kommentit aikajärjestyksessä. Tekstinäytteistä selviää sananlaskumuodon ja fraasin eli puheenparren vaihtelu. Sananlaskuille ominaisen muusta tekstistä itsenäisen lauseen sijaan tässä tapauksessa on yleisempää fraasiytimen käyttö. Käsittelen silti näitä ilmaisuja sananlaskugenreen kuuluvina, sillä fraasikin kantaa mukanaan kokonaista sananlaskuideaa, itse asiassa kokonaista satua.

\begin{tabular}{|c|c|}
\hline $\begin{array}{l}\text { Mitä lienee taustalla, mutta tuskin kultamunia munivaa kanaa pienestä syystä ulosheitetään } \\
\text { kanalasta. Mielestäni erimielisyydet ratkotaan osallisten kesken, ei julkisuudessa lehtien } \\
\text { palstoilla. Se on selkään puukottamista ja takanapäin puhumista eli juoruilua. (Ahkera } \\
\text { lukija) }\end{array}$ & $8: 01$ \\
\hline Ehdottomasti kultamunan kadottivat... (JepJep) & $10: 15$ \\
\hline Kuristivat kultamunia munivan hanhen. Puupäät. (Mummeli) & $10: 55$ \\
\hline $\begin{array}{l}\text { Wsoy:n ihmisillä näyttää olevan epäselvää, mistä yritys tienaa hölmöä } \\
\text { herkkänahkaisuutta heittää muniva kana pihalle. Tämä on tyypillistä Suomessa usein } \\
\text { esim. vastaava tilanne on maahantuojien edustajilla, jotka eivät ymmärrä, että hyvällä } \\
\text { yhteistyöllä tulokset paranevat entisestään. Varmasti kateus ja luovuus on ne puuttuvat } \\
\text { osat, kun tällaisia välirikkoja syntyy. Säälittävää Wsoy:ltä - tyypillistä sähköposti- } \\
\text { byrokratiaa, josta vedetään herne nenään. Katsotaan vain, että kohta se Wsoy:n heppu, } \\
\text { jota sofi sentään puoltaa siirtyy uuteen työhön - siihen kustantamoon, joka Sofin saa. } \\
\text { (Yrittäjä) }\end{array}$ & 11:03 \\
\hline $\begin{array}{l}\text { Luultavasti on aika hankala ihminen, tuo "molla-maija". Tuskin kustantaja kovin } \\
\text { heppoisin perustein hyvin lypsävää lehmää lopettaisi. (Molla) }\end{array}$ & $11: 10$ \\
\hline
\end{tabular}




\begin{tabular}{|l|l|}
\hline $\begin{array}{l}\text { Kyllä teki! Sofi osaa sanoa asiat suoraan niinkuin pitääkin. Ei ulkoneinen olemus } \\
\text { tee hänen kirjoistaan sen huonompia kuin muittenkaan. Jotain hämminkiähän siellä } \\
\text { ilmeisesti on kun tuollainen kultakala potkaistaan pois ja muutkin kirjailijät lähevät joko } \\
\text { potkittuna tai omasta vapaasta tahdosta. Mitä hänen kirjalliseen tuotantoon kuuluu } \\
\text { niin ihan hyvää luettavaa ne ovat minun mielestäni. Jokainenhan lukee mistä tykkää. } \\
\text { (Susirajan ihmettelijä) }\end{array}$ & $11: 20$ \\
\hline $\begin{array}{l}\text { Nimimerkille "mediasirkusta" Kirjoitat että koko juttu ei kosketa sinua. Sehän kosketti } \\
\text { sinua jopa siinämäärin että kirjoitit kommentin. Eli asia on mielenkiintoinen vaikka } \\
\text { taustoista emme tiedä. Kenen kunniaan kolahti niin, että pitää päästää vapaaksi kultamunia } \\
\text { muniva lintu? (Herkät Varpaat) }\end{array}$ & $11: 45$ \\
\hline $\begin{array}{l}\text { Tämäpä se juuri todistaa että johto ei ole tehtäviensä tasalla, kun kultamunivan } \\
\text { kanasen potkaisi pellolle. Kirjailija joka on nousussa ja "tuottaa", kelpaa kyllä muillekin } \\
\text { kustantamoille ja paremmalla sopimuksella. (Kirjaston käyttäjä) }\end{array}$ & $11: 51:$ \\
\hline $\begin{array}{l}\text { Kukas muu, kun WSOY, on niin tyhmä. Lopettivat idiootit lypsävän lehmän. } \\
\text { Sujuvathan YT-neuvottelut nyt paremmin WSOY:n kannalta!! Onpas, heh heh, fiksu } \\
\text { toimitusjohtaja!! Sofi on loistava ja vetää pisimmän korren loppujen lopuksi. (Johanna) }\end{array}$ & $11: 53$ \\
\hline
\end{tabular}

Taulukko 2 Sofi-aineistossa esiintyneet kultamuna- tai lypsävä lehmä -sananlaskun sisältävät kommentit aikajärjestyksessä.

Heti kommenttimahdollisuuden auettua jo kolmas vastaaja puolenyön jälkeen klo 00:05 tuo esiin ikään kuin esiasteen myöhemmin suositusta teemasta. Nimimerkki 'Puhdistuksen' mielipide siitä, tekikö kustantaja väärän päätöksen: ’Ilman muuta teki!!!! On tyhmää hukata kultakaivos!!!” Yön tunteina ennen kahdeksaa 16 kommentoijaa osoittautuu sananlaskujen käyttäjiksi. Tämä on $15 \%$ siihenastisten vastausten määrästä. Taulukosta 2 käy ilmi, että ensimmäinen sananlaskuaiheinen kommentti eli kultamunailmaus kirjoitetaan klo 8:01. Tämän jälkeen naputellaan 125 kommentointia kunnes jälleen esiintyy kultamuna klo 10:15. Tuossakin välissä jo $22 \%$ :ssa kommenteista on mukana jokin muu sananlasku tai muunnos.

Kommentteja kirjoitetaan varmasti useimmiten lukematta toisten tekstejä. Joka tapauksessa voimme spekuloida, vaikuttaako edellisten vastaajien tapa käyttää sananlaskuja seuraavien kommentoijien sananvalintoihin. Uskoisin, että toisinaan vaikuttaa. Esimerkiksi klo 11:03 'HeSa' kirjoittaa lyhyesti: "Kyllä maailma opettaa yli-ihmisetkin", ja neljän minuutin kuluttua 'opa': "Kyllä puhetta maailmaan mabtuu. WSOY muija on tosikko.” Kultamuna-sananlaskukuvaa käyttävän nimimerkki 'Herkkien Varpaiden' jälkeen kuuden minuutin kuluttua lähes samaan kielikuvaan päätyy 'Kirjaston käyttää' ja parin minuutin kuluttua 'Johanna' tuo vastaavan sananlaskuidean lypsävän lehmän lopettamisesta, johon on saattanut johtaa kommenttiketjussa 40 minuuttia aiemmin esiintynyt sama sananlasku. 


\section{RIITTÄÄKÖ SANANLASKU KOMMENTIKSI?}

Jotkut nettikirjoittajat ilmaisevat mielipiteensä lakonisesti. Nimimerkki 'xyz' kirjoittaa ei-äänensä perusteeksi klo 00:39: "Lyhyesti ja ytimekkäästi: EI.” Usein kommentiksi kirjoitettiin pelkkä sananlasku tai sananlasku ja sitä täydentävä sanan tai parin lisäys. Viidesosalle sananlaskua tai slogaania vastauksessaan käyttäneistä tuo ilmaus riitti sellaisenaan kommentiksi, esimerkkinä 'Turjon' mieleen noussut kansanviisaus: Ei passaa tölviä leivänantajaa. Myös puhetilanteissa sananlaskut toimivat usein lakonisina, lisäselittelyjä tarjoamattomina kiteytyksinä. Tämä ei tarkoita, että sananlaskut ilman muuta edustaisivat ekonomista ja niukkaa ilmaisua. Pikemminkin on kysymys sananlaskupuheen optimaalisuudesta suhteessa sen sosiaaliseen funktioon (Lauhakangas 2004, 22). Varsinkin 'Päivän kysymyksen' kaltaisen uutisaiheen herättämässä nettiviestinnässä nopeatempoinen kirjoittaminen muistuttaa ikään kuin puheenvuorojen vaihtamista, jossa pitkät mielipidekirjoitukset ovat vähemmistönä. Vain $7 \% 344$ kommentin aineistosta oli yli 50 sanan pituisia. Yhden tai kahden virkkeen repliikit soveltuvat kommentiksi. Tosin pelkästään lauseen pituus ei vaikuta sen luettavuuteen. Pitkät lauseet tapaavat olla lyhyitä monimutkaisempia ja toisinaan niistä puuttuu huolellisesti harkitun lyhyen lauseen napakkuus. Ymmärrettävyyden kannalta ratkaisevinta on lauseen syntaktinen rakenne. (Virtaluoto \& Väyrynen 2000, 2.) Juuri ajan hioma suhteellisen lyhyt rakenne, symmetria ja varsinkin suomalaisissa sananlaskuissa alkusointu eli allitteraatio ovat sananlaskujen valtteja. (Mieder 2004, 6-7; Niemi 1926, 121-182.)

Sananlaskun nopeakäyttöisyyttä selittää tutkijoiden havainto, että konventionaalisten ilmaisujen toistuva käyttö saa ihmisen käytännön tilanteissa ohittamaan prosessoinnin, jota kirjaimellisen ja metaforisen tulkinnan välisen kytkennän luulisi vaativan. Käyttäjä yksinkertaisesti palauttaa sananlaskun tai vastaavan ilmaisun sopivassa tilanteessa kokonaisuutena mieleensä. (Gibbs \& Beitel 1995, 131, 149.) Sama tilannevihjeiden ja tutun ilmaisun yhdistävä välitön lukutapa pätee myös muihin yleistäviin lausahduksiin. Virolainen fraseologi Anneli Baran viittaa Rachel Gioran tutkimuksiin, jotka osoittavat, että idiomien salienssi (niiden tulkinnassa näkyvin ja keskeisin elementti) muodostuu niille asteittain eikä sekään edellytä idiomin osien kirjaimellista ymmärtämistä (Baran 2011, 60-61; Giora 2003, 10).

Puhetilanteissa sananlaskun tyypillisimpänä paikkana voi pitää keskustelun tai puheenvuoron loppua. Neuvottelevassa ja perustelevassa puheessa tarvitaan loppuyhteenvetoja. Toiminnan lopputulokselle tarvitaan selitys tai tarinalle opetus. (Lauhakangas 2004, 199-202, 240.) Sananlaskuja käytetään, kun pyritään ohjaamaan keskustelua ainakin näennäiseen yksimielisyyteen ja päätökseen. Kysymys on vallan tai vähintään vaikutusvallan käytöstä. Tämä sananlaskupuheen funktio näkyy pätevän pitkälti myös kirjoittamalla käytyyn mielipiteiden vaihtoon. Sofi-aineiston sananlaskujen käyttäjistä 68 \% päättää äänestyksensä perustelun joko ytimekkääseen sananlaskuväittämään tai pitkähköön sananlaskumaiseen ilmaukseen.

Sofi-aineisto kuitenkin osoittaa, että kirjoitustilanteessa sananlasku tai sen muunnos voi esiintyä toisinaan alussa otsikon tavoin. Tästä on kysymys myös sananlaskun nimimerkikseen valinneiden argumentointitavassa. Usein kiteytynyt tuttu ilmaus on myös keskellä tekstiä jäsentämässä pidempää pohdintaa. Kirjoittaminen poikkeaa 
Outi Lauhakangas: Internetin keskustelufoorumit sananlaskujen kasvualustana

kasvokkaisesta vuorovaikutuksesta ainakin visuaalisuutensa osalta. Oma kommentti annetaan pikemminkin vaikuttavana kuvana kuin kuunneltavana repliikkinä. Otsikolla ja kehystämisellä on merkitystä.

\section{ANONYYMISYYS JA RYHMÄIDENTITEETTI}

On mahdollista rakentaa hypoteeseja siitä, missä määrin ihmisillä on taipumus nettivuorovaikutuksessa ottaa vaikutteita tilapäisiltä kommunikaatiokumppaneiltaan. Toisaalta on muistettava myös löyhien yhteisöjen muodostuminen eri foorumeille, nopeasti syntyvät roolit, joita ahkerat osallistujat saavat ja ottavat itselleen. Voidaankin kysyä, mikä funktio sananlaskulla on käyttäjälleen, kun hän tuo sen nettivuorovaikutukseen. Toimivatko sananlaskut minä-puheesta etäännyttäjinä ja auktoriteettiin vetoamisena, kun niitä käytetään kommenttien vahvistajina tai sellaisinaan kommentteina? Vai vaikuttaako valmiiksi etäännytetyssä anonyymissä tilanteessa pikemminkin tarve lähentyä samanmielisiä sananlaskun käytön avulla, luoda tuttuuden siltaa muihin kommentaattoreihin ja lukijoihin?

Ihmisten erilainen henkilökohtainen tausta, ikä ja kirjoittamiskokemukset vaikuttavat siihen, edustaako nettikirjoittaminen heille lehden yleisönosastoa, vieraskirjaa, käymälän seinää, päiväkirjaa vai ovatko he diginatiiveina kasvaneet eriytyneiden foorumien, blogien, chattien ja kommenttiluukkujen maailmaan. Silti on oman mielipiteen huomatuksi tulemisen kannalta eroa siinä, kirjoittaako ihminen anonyyminä satunnaisesti täysin tuntemattomalle ihmisjoukolle vai suhteellisen pysyvän nimimerkin takaa toisille nimimerkki-ihmisille, jotka hän on aikaa myöten oppinut tunnistamaan nettifoorumilla. Zuoming Wang (2007, 21-22) raportoi empiirisistä tutkimuksista, joiden mukaan anonyymi vuorovaikutus netissä voi hälventää eroavaisuuksia ryhmän sisällä ja näin vahvistaa ryhmätietoisuutta. Toisin kuin aiemmin on oletettu ihmiset eivät suinkaan menetä yksilöllistä identiteettiään ja itsetietoisuuttaan toimiessaan ryhmässä anonyymeinä. He ikään kuin kääntävät vaihteen yksilöllisestä identiteetistä ryhmäidentiteetin suuntaan.

Sananlaskujen käytön perusfunktioista kahden eli 'perinteen siirtymisen' ja 'kielellisen vaikutusvallan' (Lauhakangas 2004) kannalta on kiintoisaa, miten auktoriteettiasema saavutetaan näennäisen tasavertaisessa nettivuorovaikutuksessa. Internetin psykologiaan perehtynyt Patricia Wallace $(1999,9)$ torjuu käsityksen netistä jonkinlaisena maailmankylänä. Internet jakautuu erilaisiin ympäristöihin samaan tapaan kuin elämänpiiri, jossa muutoin liikumme. Ratkaisevaa on motivaatio ja tarkoitus, joka saa ihminen kuhunkin ympäristöön menemään. Voidaan siis olettaa, että nettivuorovaikutuksessakin ihmiset pyrkivät noudattamaan aiemmin omaksumiaan käytäntöjä -myös ryhmäytymistä.

Pirkko Muikku-Werner $(2009,109)$ tulkitsee metaforia viljelevän kielenkäytön selittyvän osittain ryhmän sosiaalisesta käyttäytymisestä. Hän pohtii tekstien kuvallisuuden keskeistä asemaa silloin, kun keskusteluyhteisön kielenkäyttö noudattaa tiettyjä konventioita. Pitkään samoilla nimimerkillä yhteisellä foorumilla kirjoittaneiden voi olettaa jo tuntevan kuuluvansa virtuaaliseen ryhmään. Jos nettifoorumikirjoittaminen voidaan tulkita omaksi tekstilajikseen, on mahdollista tutkia siellä kirjoittamisen kon- 
ventioita ja sitä, millainen käyttäytyminen rikkoisi näitä rajoja (esim. van Peer 1986, 17-18). Nettifoorumilla sävyjen, kuten ironian tai lempeän huumorin ilmaiseminen vaatii enemmän kuin näiden välittäminen puhetilanteessa. Toisaalta anonyymissä kirjoittamisessa on usein kyseenalainenkin "vapaus" sanoa kiertelemättä ajatuksensa. Vaikka tämä esteettömyys (ellei moderaattorien sensurointioikeutta oteta huomioon) vallitsee nettifoorumeilla, kaikki eivät suinkaan valitse suoraa ilmaisutapaa. Helsingin Sanomien keskustelupalstoilla on luettavissa käyttäytymisohjeet ${ }^{10}$, joiden mukaiset kommentit eivät tule sensuroiduiksi. Ei tule kiroilla, jankuttaa, haukkua toisia tai HUUTAA. Eräs säännöistä on sananlaskujen käytön kannalta kiintoisa: Älä kirjoita, mitä et sanoisi kasvokkain!

Varmasti virallisista säännöstöistä riippumatta eri foorumeilla tavattava puhetapojen kirjo on riippuvaista sekä viestimen sosiaalisesta statuksesta että siitä, millaisia puhetapoja yhteisö sallii. Mielenkiintoista olisikin vertailla eri foorumien julkaisemia sääntöjä ja käyttäytymisideaaleja suhteessa niihin kielenkäytön konventioihin, joita keskusteluista voi tunnistaa. Tavat, joita ihmiset noudattavat anonyymeinä pysytellen keskustelufoorumeilla eivät ole syntyneet ainoastaan uuden välineen ehdoilla, vaan niihin ovat vaikuttaneet osallistujien aiemmat, useimmiten kasvotusten tai vähintään puhetilanteissa opitut vuorovaikutustaidot. Arpon (2005) tutkimus internetin keskusteluryhmistä osoitti, että kysymys läsnäolosta ja luetuksi tulemisesta on keskeistä. Ihminen ei ilmaise asioita vain muihin vaikuttaakseen, vaan rakentaa samalla käsitystä itsestään ja suhteestaan muihin.

\section{IDENTITEETIN RAKENTAMINEN NETTIFOORUMILLA}

Nettivastaamiselle on leimallista ainakin näennäinen anonyymiys ja tilapäisyys. Ihmiset voivat luoda itselleen tapauskohtaisen pikaidentiteetin ja käydä foorumilla ilmaisemassa mielipiteensä palaamatta enää samaan virtuaaliympäristöön koskaan uudelleen. Joidenkin tutkijoiden mielestä nettifoorumeilla ylläpidettävä identiteetti voi olla soveltajalleen sosiaalisesti palkitsevampi kuin oma arkiminä. Tämä online-identiteetti saa enemmän kunnioitusta ja huomiota kuin offline-identiteetti. (Wallace 1999, 54.) Anonyymiys ja tilapäisyys on suhteellista, sillä toistuva saman nimimerkin käyttö lisää tunnistettavuutta ja luo ikään kuin yhteisöön kuulumisen aseman. Aktiivinen keskustelija omaksuukin usein pysyvän nimimerkin, jota käyttää myös muilla foorumeilla. Tähän ainakin Helsingin Sanomien verkkokeskusteluissa liikkuvaa jopa kehotetaan. Hän voi sisällyttää nimimerkkiinsä vihjeitä iästään, sukupuolestaan, suuntautumisistaan ja asenteistaan, vaikka ei paljastaisi henkilöllisyyttään.

Oma selityksiä antava ja perusteleva sananlaskupuhe palvelee myös itsekunnioitusta ja kannattelee omien arvojen konsistenssia eli ristiriidattomuutta. Siihen, kuinka julkiselle ja laajasti luetulle foorumille nettikommentoija tuntee ja ymmärtää kirjoittavansa, vaikuttaa varmasti välineen asema yhteiskunnallisella keskustelukentällä. Vaikutusvalta,

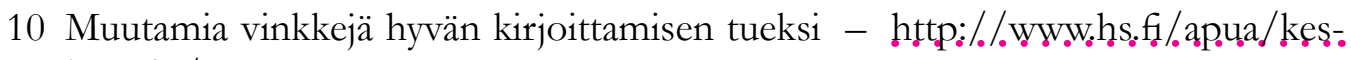
kuşstelęų/ 
jota Helsingin Sanomien paperilehdellä on niin sanottuun yleiseen mielipiteeseen perinteisesti maassamme ollut, houkuttaa nettifoorumeilleen todennäköisesti kirjoittajia, joilla on vahva kanta yhteiskunnallisiin tai moraalisiin kysymyksiin. Sananlaskuja tai niiden muunnoksia käytetään usein lehtikirjoitusten otsikoissa. Toimittajat lainaavat myös poliitikkojen puheista mielellään niitä repliikkejä, joihin liittyy heidän käyttämiään värikkäitä sanontoja. Vanhatkin sanonnat lähtevät uudelleen kiertoon, jos joku nimekäs henkilö niitä julkisuudessa käyttää. Näin ollen ei ole yllättävää, että myös sanomalehden keskustelufoorumilla sananlaskujen käyttö koetaan hyväksytyksi tavaksi perustella omaa kantaansa.

Sananlaskujen käytön kannalta nettikeskustelun tilanne on uusi, kun teksti-puhe jää useimmiten kohdistamatta kenellekään tai kun sen vastaanottajista ei ole tietoa. Perinteisesti sananlaskuja käyttävä puhe on kohdistettu jollekulle suoraan tai välillisesti. Mielipide ilmaistaan kasvokkain tai toisen tekemisiä kommentoidaan takanapäin. (Lauhakangas 2004.) Kun sananlaskujen tai niiden muunnosten esiintyvyyttä selvittää, olisikin aihetta pohtia, kuinka paljon eri nettifoorumien välillä on eroja ryhmäkokemuksen ja anonyymisyyden asteen kannalta.

Vielä on tutkimatta, kuinka paljon anonyymisyys internetin foorumilla saattaa jopa voimistaa tarvetta nostaa oman mielipiteen uskottavuutta sananlaskumaisilla ilmauksilla. Sananlaskumaisten ilmaisujen suosiminen viittaa siihen, että nettitilanteissa syntyy puhetilanteisiin verrattava tarve tuoda sosiaalisiin vuorovaikutustilanteisiin sopivaa etäännyttämistä ja puolueettomuutta, sillä sananlaskujen teho perustuu yleistävyyteen ja "kolmannen tahon" ääneen. (Lauhakangas 2004, 263; Mukařovský 1983.)

\section{JÄLKIMIETTEITÄ JA JOHTOPÄÄTÖKSIÄ}

Ensivaikutelmani valitsemani Helsingin Sanomien 'Päivän kysymyksen' kommenttien antoisuudesta sananlaskututkimuksen kannalta osoittautui oikeaksi. Kulttuurisena kommunikaatiomuotona nettikeskustelu on nykyisessä laajuudessaan muuttunut harvojen harrastuksesta jokapäiväiseksi ilmiöksi. Sen avaamat tutkimusmahdollisuudet ovat varsinkin sananlaskujen funktioiden selvittämiseksi suorastaan ideaalit. Pohdin edellä, että sananlaskut elävät perinteenlajina uutta kehitysvaihetta. Jos nettikirjoittamisen erilaisia tarpeita, yhteyksiä ja jopa yhteisöjä ei oteta huomioon, syntyy helposti käsitys, että vain sananlaskumuunnokset, hauskat motot ja vitsit elävät Internetin vuorovaikutustilanteissa. Tässä aineistossa yllätti runsas perinteisten ilmaisujen käyttö suhteessa sananlaskumuunnoksiin ja kielileikkeihin. Parodioivia sananlaskuja oli Sofiaineistossa erityisen vähän. Muunnoksetkin näyttivät palvelevan mielipiteen ilmaisua.

Povaamani uusi kehitysvaihe saattaa merkitä, että sosiaalisissa vuorovaikutustilanteissa, toisin sanoen erilaisissa puhetilanteissa opitut perinteiset sananlaskut nousevat varsinkin sosiaalista jännitettä herättävissä tilanteissa myös nettikommentteja kirjoittavien mieleen. Kirjailija Sofi Oksasen irtisanominen vuoden 2010 kesän alussa herätti ainakin kahdensuuntaisia tunnereaktioita, kun kustantajan ratkaisun oikeutta tai vääryyttä kyseltiin. Voimakkaimmin näkyivät negatiiviset ja paheksuvat reaktiot. Silti aineiston analyysi osoitti, että kaksijakoiseen vastaamiseen pakottava äänestäminen herätti tarpeen selittää ja perustella valintaansa puolesta tai vastaan. 


\section{Outi Lauhakangas: Internetin keskustelufoorumit sananlaskujen kasvualustana}

Perustelevaa puhetta vaativat ja toiminnan lopputulosta selittävät tilanteet ovatkin sananlaskujen käytön kannalta erityisen yllyttäviä (Lauhakangas 2004). Sofi-aineisto osoitti, että oman kannan tueksi oltiin valmiita lainaamaan sananlaskua tai sananlaskun kaltaista ilmaisua. Tarkemmin tutkien sananlaskujen käyttö oli usein omiaan lieventämään ja siirtämään jyrkkää kannanottoa yleisemmälle tasolle. Sananlaskujen sosiaalinen funktio on eri asteisten jännitteiden purkamisessa tai yhteenkuuluvuuden vahvistamisessa. Tutun tuntuiseen mielikuvaan tai sen parodiaan viittaava ei laita itseään liiaksi peliin ja tulee silti kuulluksi tai luetuksi.

Vaikka aineistoni nettikirjoittajista suuri osa ei erityisesti ajattelisi käyttävänsä sananlaskuksi luokiteltavaa perinteenlajia mielipidetekstilajissa, heidän tapansa käyttää näitä ilmaisuja tuntuu vastaavan puhetilanteiden sananlaskujen käyttöä. Pohdin jo edellä identiteetin rakentamista keskustelufoorumilla, osallistujien tarvetta tuoda esiin jotain itsestään anonyymiyden ollessa nettifoorumin normi. Nimimerkeissä näkyi, olipa kyse todellisuudesta poikkeavan roolin esittämisestä tai ei, halua luoda itselle ainakin tilapäinen identiteetti muita keskustelijoita varten. Usein nimimerkki oli linjassa kommentin sisällön kanssa, joskus sisältöä tuki otsikoksi otettu sananlasku.

Aivan kuten uusien sanontojen leviämisen myös sananlaskuperinteen välittymisen kannalta internet on tehokas. Sofi-aineiston kommentointi muistuttaa tiivistahtisuudessaan toisen puheen päälle puhumista. Vaikka ei ole keinoa selvittää, missä määrin uusi kommentoija lukee muiden kirjoittamia repliikkejä, kirjoittamisessa on välittömän vuorovaikutuksen ja keskustelun tuntu. On vaikea todistaa yksittäisen henkilön sananlaskujen käytön vaikutusta muihin kirjoittajiin, mutta ainakin suosituin sananlaskutyyppi, jossa toistui kultamunia munivan kanan/hanhen/linnun metafora, saattoi kirjoitusajoista päätellen kasvattaa suosiotaan kommentoinnin aikana.

Tuntuisi mahdottomalta tehtävältä vertailla tutkitun kaltaista puolen vuorokauden pituista jaksoa muunlaisiin kuin toisiin nettikommentointitilanteisiin. Kuka onnistuisi esimerkiksi jollakin työpaikalla keräämään päivän ajalta talteen sananlaskujen ja muiden värikkäiden ilmausten käyttöä jonkin tunteita herättävän uutisen kuulleiden keskuudessa? On aihetta pohtia, olisivatko nämä puhetilanteet toisiaan tuntevien henkilöiden välisine jännitteineen aidompia kuin vastaava nettikommentointi sananlaskujen sosiaalisten funktioiden tutkimisen kannalta.

Lopuksi on tarpeen pohtia käyttämääni aineistoa arvioiden yleisemminkin internetin aineistoihin palaamisen vaikeutta ja tutkimuseettisiä ongelmia. Vaikka aineistot ovat helposti saatavilla, voi niiden alkulähteisiin olla jälkikäteen vaikea viitata ${ }^{11}$. Keskustelufoorumin julkisuus ja aiheen yleisyys varmistavat, että tekstin analysointi ei loukkaa kirjoittajien yksityisyyden suojaa. Aineistoksi valitsemani keskustelun koostuminen spontaaneista kommenteista lisää sen tutkimuksellista arvoa. Kysymys ei ollut monen kirjoituskeruun lailla kilpailusta, jossa kommentoijat olisivat tietoisesti

11 Artikkelia varten puoli vuotta ennen kirjoitusvaihetta kopioitu nettiaineisto on poistettu Helsingin Sanomien sivustoilta. Se on ehkä arkistoissa, mutta tuskin kenen tahansa tutkimusaineistosta kiinnostuvan luettavissa. Näin ainoa tapa saada aineisto uudelleen lähiluettavaksi on pyytää se kirjoittajan omasta kotiarkistosta tiedostona luettavaksi. 
pyrkineet "pääsemään" palkituiksi keruuaineistojen tuottajiksi tai käyttäneet tutkijoita miellyttääkseen sananlaskuja.

\section{KirjallisuUs}

ARPO, ROBERT 2005: Internetin keskustelukulttuurit. Tutkimus internet-keskusteluryhmien viesteissä rakentuvista puhetavoista, tulkinnoista ja tulkinnan kehyksistä kommunikaatioybteiskunnassa. Joensuun yliopiston humanistisia julkaisuja 39. Joensuu: Joensuun yliopisto.

BARAN, ANNELI 2011: Fraseologismide semantika unimisvõimalused. Tartu: Tartu Ülikool.

CRAM, DAVID 1994 [1983]: The linguistic status of the proverb. - W. Mieder (ed.), Wise words: Essays on the proverb, 73-97. New York: Garland.

DOMÍNGUEZ BARAJAS, ELÍAS 2010: The Function of Proverbs in Discourse. The case of a Mexican transnational social network. Berlin/New York: De Gruyter Mouton.

GIBBS, RAYMOND W. \& BEITEL, DINARA 1995: Does proverb understanding really reflect abstract thought? - Psychological Bulletin 118 (1).

GIORA, RACHEL 2003: On our mind: salience, context, and figurative language. Oxford: Oxford University Press.

GRANBOM-HERRANEN, LIISA 2008: Sananlaskut kasvatuspubeessa - perinnettä, kasvatusta, indoktrinaatiota? Jyväskylä studies in education, psychology and social research 329. Jyväskylä: Jyväskylän yliopisto.

HAIN, MATHILDE 1951: Sprichwort und Volksprache. Eine volkskundlich- soziologische Dorfuntersuchung. Giessen: Schmitz.

KUUSI, MATTI 1988: Rapatessa roiskuu. Nykysuomen sananparsikirja. Helsinki: Suomalaisen Kirjallisuuden Seura.

- 1954: Sananlaskut ja pubeenparret. Helsinki: Suomalaisen Kirjallisuuden Seura.

LAUHAKANGAS, OUTI 2009a: Present use of old Finnish proverbs. - Lauhakangas, Outi \& Soares, Rui (toim.), The $2^{\text {nd }}$ Interdisciplinary Colloquium on Proverbs. ACTAS ICP08 Proceedings. Tavira: International Association of Proverbs.

- 2009b: Nettiluovuus ja sananlaskumuotti. - Knuuttila, Seppo ja Piela, Ulla (toim.), Korkeempi kaiku. Sanan magiaa ja pubeen poetiikekaa. Kalevalaseuran vuosikirja 88. Helsinki: Suomalaisen Kirjallisuuden Seura.

- 2009c: Sananlaskumuotti nettiteksteissä. - Heikkinen, Vesa (toim.). Kielen piirteet ja tekstilajit. Vaikuttavia valintoja tekstilajista toiseen. Helsinki: Suomalaisen Kirjallisuuden Seura.

-2007: Proverbs in Social Interaction: Questions Aroused by the Multi-Functionality of Proverbial speech. - Proverbium 24.

- 2004: Pubeesta ibminen tunnetaan. Sananlaskujen funktiot sosiaalisessa vuorovaikutuksessa. Helsinki: Suomalaisen Kirjallisuuden Seura.

- 2001: The Matti Kuusi International Type System of Proverbs. FF Communications 275. Helsinki: Academia Scientiarum Fennica. 
Outi Lauhakangas: Internetin keskustelufoorumit sananlaskujen kasvualustana

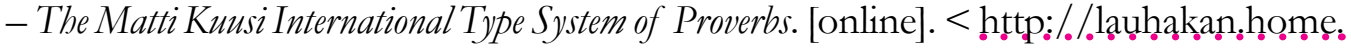



LAUKKANEN, KARI \& HAKAMIES, PEKKA 1984: Sananlaskut. Helsinki: Suomalaisen Kirjallisuuden Seura.

MIEDER, WOLFGANG 2004: Proverbs. A Handbook. Westport, Connecticut \& London: Greenwood Press.

MUIKKU-WERNER, PIRKKO 2009: Kirja-arvostelujen metaforat ja niiden kohosteisuus. - Vesa Heikkinen (toim.): Kielen piirteet ja tekstilajit. Vaikuttavia valintoja tekstistä toiseen. Helsinki: Suomalaisen Kirjallisuuden Seura.

MUKAŘOVSKÝ, JAN 1983 [1971]: The Proverb as Part of Context. Selected passages from Mukařovský, Jan \& Penfield, Joyce, Communicating with quotes: The Igbo case, 96-104, Appendix B. Westport CT: Greenwood Press.

MÄKINEN, ESA 2010. WSOY:n mitta tuli täyteen: Sofi Oksanen saa lähteä. - Helsingin Sanomat 16.6. 2010.

PENFIELD, Joyce 1983: Communicating with quotes: The Igbo case. Westport CT: Greenwood Press.

PRAHLAD, ANAD SW. 1996: African American Proverbs in Context. Jackson (MS): University Press of Mississippi.

PRENSKY, MARC 2001: Digital Natives, Digital Immigrants. - On the Horizon, 9 (5).

SEITEL, PETER 1977: Saying Haya sayings: Two Categories of Proverb Use. - J. D. Sapir \& , J. C. Crocker (eds), The Social Use of Metaphor. Essays on the anthropology of rhetoric, 75-99. Philadelphia: University of Pennsylvania Press.

VAN PEER, WILLIE 1986: Stylistics and Psychology. Investigations of foregrounding. London: Croom Helm.

VIRTALUOTO, JENNI \& VÄYRYNEN, PIRJO 2000: Voidaanko tekstin luettavuntta

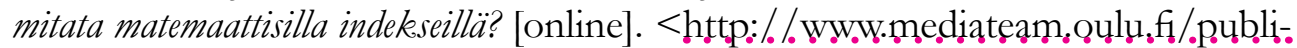
cạtionsos.p.pdff/70.pdff > [19.4.2011.]

WALLACE, PATRICIA 1999: The Psychology of the Internet. Cambridge: Cambridge University Press.

WANG, ZUOMING 2007: Anonymity Effects and Implications in the Social Identity Model of Deindividuation: From Crowd to Computer-Mediated Communication. [online]. $<$ h̦țtp:/./.



WINICK, STEPHEN D. 2003: Intertextuality and Innovation in a Definition of the proverb Genre. - Mieder, Wolfgang (ed.), Cognition, Comprehension, and Communication. A decade of North American Proverb Studies (1990-2000). Phraseologie und Parömiologie 13. Essen: Schneider Verlag Hohengehren, Baltmannsweiler.

VIRKKUNEN, SAKARI 1974: Suomalainen fraasisanakirja Kivestä Kekkoseen. Helsinki: Otava.

YANKAH, KWESI 1989: The proverb in the context of Akan rhetoric: a theory of proverb praxis. Bern: Lang.

Outi Lauhakangas on helsinkiläinen valtiotieteiden tohtori, sosiaalipsykologi ja sananlaskuihin erikoistunut tutkija. Hän toimii myös Hiidenkivi-lehden vastaavana toimittajana. 